Technical Note

\title{
Effects of Temperature on Electrostatic Precipitators of Fine Particles and $\mathrm{SO}_{3}$
}

\author{
Haibao Zhao ${ }^{*}$, Yuzhong He ${ }^{1}$, Jiadong Shen ${ }^{2}$ \\ ${ }^{1}$ Zhejiang Feida Environmental Science and Technology Co., Ltd., Zhuji 311800, China \\ ${ }^{2}$ Tongji Zhejiang College, Jiaxing 314051, China
}

\begin{abstract}
The fine particles and $\mathrm{SO}_{3}$ at the outlets of electrostatic precipitators (ESPs) were measured when the temperature of the flue gas decreased to $90^{\circ} \mathrm{C}$ on a pilot-scale platform with $50,000 \mathrm{~m}^{3} \mathrm{~h}^{-1}$ of real flue gas. Based on the test results, the mechanism of fine particle change and $\mathrm{SO}_{3}$ removal was analyzed. The results show that the efficiency of $\mathrm{SO}_{3}$ removal reaches $73 \%$ and the penetration concentration of $\mathrm{PM}_{1}$ decreases from 0.5 to $0.17 \mathrm{mg} \mathrm{m}^{-3}$ when the gas temperature decreases from $120-130^{\circ} \mathrm{C}$ to $90-95^{\circ} \mathrm{C}$ in a coal-fired power plant.
\end{abstract}

Keywords: Coal-fired power plant; Dust emission; Electrostatic precipitator; $\mathrm{SO}_{3} ; \mathrm{PM}$.

\section{INTRODUCTION}

As air pollution has been a serious problem, the ultralow emission in China requires that the particles emissions must be less than $10 \mathrm{mg} \mathrm{m}^{-3}$ (Saeki et al., 2003; Ando et al., 2011; Nicol et al., 2013; Preston et al., 2013; China et al., 2015).

The collection efficiency of electrostatic precipitator (ESP) is over $99.9 \%$. However, the difficulty of charging is one of the major limiting factors for particles collection of ESP (Kato et al., 1994; Yi et al., 2006; Roudier et al., 2013; Afshar-Mohajer et al., 2014; Xu et al., 2015), and the mass concentration at the outlet of ESP was about $50 \mathrm{mg} \mathrm{m}^{-3}$ with high penetration efficiency of dust particles in the size range of 0.1-1 $\mu \mathrm{m}$ (Tamaru et al., 1998; Misaka et al., 2009). Chang et al. (2015) had enhanced particles agglomeration by using a pre-charger to increase mean particle size but without reducing the dust resistivity and taken more power.

There are some ESPs operated at different gas temperatures in coal-fired power plants (Xia et al., 2011; Li et al., 2017), Hitachi Plant Technologies developed a gas treatment system with a low temperature electrostatic precipitator (LLT-ESP), the moving electrode type ESP with gas temperature of $90^{\circ} \mathrm{C}$ was described (Misaka et al., 2008). In 2016, the industrial standard of LLT-ESP was implemented in China (JB/T 12591-2016), but there is few study focused on its mechanism. Thus, this paper will describe the major

\footnotetext{
* Corresponding author.

E-mail address: zhaohaibaozj@163.com
}

performances of LLT-ESP and the changes to ESP at different gas temperatures by tests.

\section{TEST}

\section{Testing Apparatus}

\section{(1) Pilot-scale Platform}

The pilot-scale platform (Fig. 1) was built beside a real coal-fired power plant. The flue gas of the pilot-scale platform was pumped from a 300 MW heat-supply unit in Heibei plant after the economizer, thus ensured that the characters of flue gas in the pilot-scale platform. The flue gas volume is $50,000 \mathrm{~m}^{3} \mathrm{~h}^{-1}$ in $350^{\circ} \mathrm{C}$ while $32,221 \mathrm{~m}^{3} \mathrm{~h}^{-1}$ in $90^{\circ} \mathrm{C}$.

The main parameters of LLT-ESP in the pilot-scale platform is shown in Table 1, which includes of the main components of coal and ash, the inlet flue gas parameters during the texts. The LLT-ESP pilot-plan is shown in Fig. 2.

(2) Test ESPs in 300-1000 MW Coal-fired Power Plants The three ESPs were set in Changxing coal-fired plant (Power plant name, the unit capacity is $660 \mathrm{MW}$ ), Shangan coal-fired plant (the unit capacity is $660 \mathrm{MW}$ ) and Ninghai coal-fired power plant (the unit capacity is $1000 \mathrm{MW}$ ) for in-depth study of the performances of LLT-ESP in large units. The main parameters of ESPs and the entrance flue gas parameters are shown in Table 1.

\section{Experiment Devices and Methods}

In this paper, to test the dust concentrations, $\mathrm{SO}_{3}$ concentrations and dust practical resistivity of LLT-ESP, the following test data got by the equipment and method are shown in Table 2. 


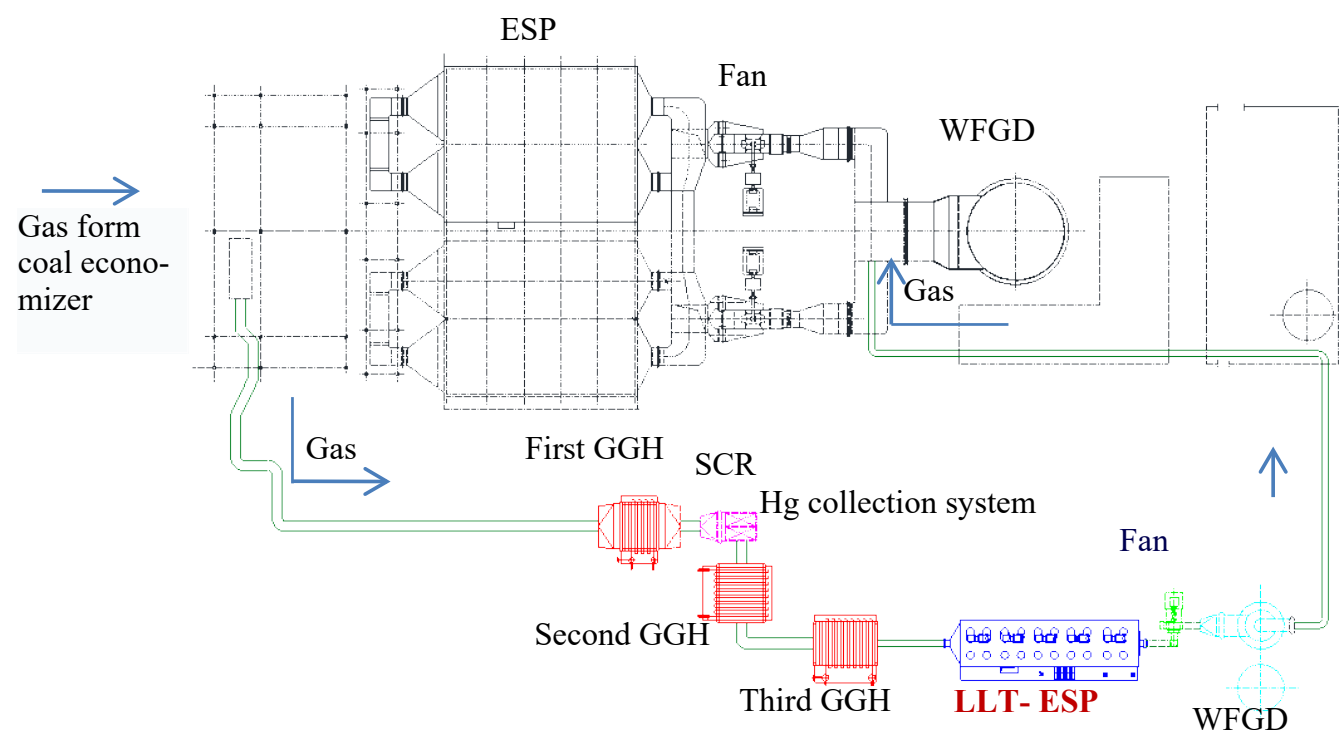

GGH means gas-gas heater, SCR means selective catalytic reduction

Fig. 1. System diagram of pilot-scale platform.

Table 1. Main parameters of LLT-ESPs and flue gas parameters during followed tests.

\begin{tabular}{|c|c|c|c|c|c|}
\hline Item & name & $\begin{array}{l}\text { LLT-ESP } \\
\text { pilot-plan } \\
\text { platform } \\
\text { (Zhao et al., 2016; } \\
\text { Wu et al., 2018) }\end{array}$ & $\begin{array}{l}\text { LLT-ESP in } \\
\text { Changxing } \\
\text { plant } \\
\text { (He et al., 2013) }\end{array}$ & $\begin{array}{l}\text { LLT-ESP in } \\
\text { Ninghai plant }\end{array}$ & $\begin{array}{l}\text { LLT-ESP in } \\
\text { Shangan plant }\end{array}$ \\
\hline Main & Design Dust Collection Efficiency/\% & $\geq 99.87$ & $\geq 99.782$ & $\geq 99.93$ & $\geq 99.93$ \\
\hline Parameters of & Guaranteed Particle Emission $/ \mathrm{mg} \mathrm{m}^{-3}$ & $\leq 20$ & $\leq 20$ & $\leq 15$ & $\leq 20$ \\
\hline \multirow[t]{2}{*}{ ESPs } & $\begin{array}{l}\text { Number of ESP per boiler, electric } \\
\text { field }\end{array}$ & $1,4+1$ & 2,5 & 2,4 & $2,4+1$ \\
\hline & $\begin{array}{l}\text { SCA of LLT-ESP } / \mathrm{m}^{2}\left(\mathrm{~m}^{3} \mathrm{~s}^{-1}\right)^{-1} \\
\text { power supply }\end{array}$ & $\begin{array}{l}124.52 \\
\text { high-frequency }\end{array}$ & $\begin{array}{l}162.1 \\
\text { high-frequency }\end{array}$ & $\begin{array}{l}81.01 \\
\text { high-frequency } \\
+ \text { pulsed }\end{array}$ & $\begin{array}{l}85.33+16.33 \\
\text { high- } \\
\text { frequency }\end{array}$ \\
\hline Entrance Flue & Gas Flow Rate $/ \mathrm{m}^{3} \mathrm{~h}^{-1}$ & 32221 & 2742800 & 8243956 & 2091580 \\
\hline \multirow[t]{3}{*}{ Gas Parameters } & Inlet Dust Loading $/ \mathrm{g} \mathrm{m}^{-3}$ & 15.735 & 11.55 & 11.735 & 28.589 \\
\hline & Gas Temperature $/{ }^{\circ} \mathrm{C}$ & 90 & 88.25 & 90 & 95 \\
\hline & $\mathrm{D} / \mathrm{S}$ & 605 & 195 & 323 & 261 \\
\hline Main & Moisture & 16.20 & 21.1 & 14.00 & 8.1 \\
\hline Components of & Received Base Ash & 12.80 & 6.60 & 7.04 & 23.81 \\
\hline \multirow[t]{5}{*}{ Coal $/ \%$} & $\begin{array}{l}\text { The Yankees Coal Ash Dry without } \\
\text { Volatile Matter Content }\end{array}$ & 37.05 & 8.82 & 33.19 & 15.84 \\
\hline & Carbon & 56.32 & 58.00 & 63.25 & 62.39 \\
\hline & Hydrogen & 3.40 & 2.99 & 3.40 & 2.97 \\
\hline & Oxygen & 10.03 & 10.13 & 11.18 & 2.61 \\
\hline & Nitrogen & 0.77 & 0.61 & 0.64 & 0.96 \\
\hline Main Ash & Sulfur & 0.49 & 0.57 & 0.50 & 1.32 \\
\hline Characteristics/ & $\mathrm{SiO}_{2}$ & 41.32 & 42.98 & 26.31 & 55.66 \\
\hline \multirow[t]{2}{*}{$\%$} & $\mathrm{Al}_{2} \mathrm{O}$ & 32.09 & 27.92 & 12.66 & 29.55 \\
\hline & $\mathrm{Na}_{2} \mathrm{O}$ & 5.14 & 2.98 & 0.43 & 0.45 \\
\hline
\end{tabular}

The measurement of dust concentration was on the basis of ISO 12141-2002. The sampling points were set at the inlet and outlet of ESP. The PM was sampled by a normal sample tube, a glass fiber cartridge at the inlet of ESP and by a low concentration sample tube, quartz membranes at the outlet of ESP, respectively. Especially, the gas was sampled with a heating sample tube by isokinetic sampling. The fiber cartridges or membranes were weighed before and after by an electronic balance in tens of millions.

The measurement method of $\mathrm{SO}_{3}$ was on the basis of GBT 21508-2008 as shown in Fig. 3. The gaseous $\mathrm{SO}_{3}$ would become mist $\mathrm{SO}_{3}$ when the flue gas temperature was 


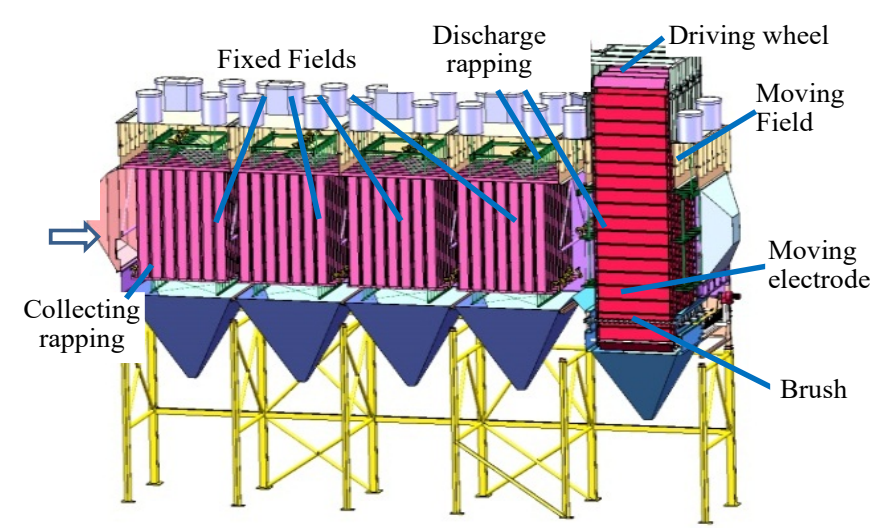

(a)

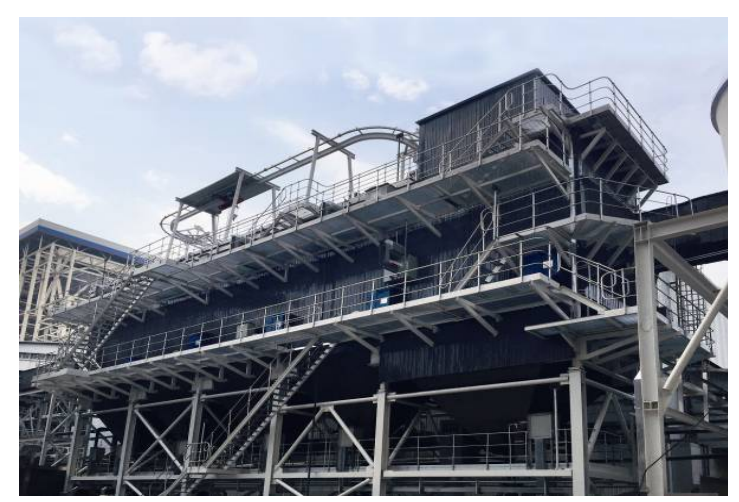

(b)

Fig. 2. Sketch of LLT-ESP pilot-plan (a) Schematic diagram and (b) Reality images.

Table 2. The measurement equipment and method (ISO 12141, 2002; GB/T 21508, 2008; GB/T 16913, 2008; JB/T 12591, 2016; Li et al., 2017; Wu et al., 2018; Liu et al., 2018).

\begin{tabular}{|c|c|c|c|}
\hline Items & Measurement Equipment & Instrument Types & $\begin{array}{l}\text { Reference Standards } \\
\text { or Methods }\end{array}$ \\
\hline Dust Concentrations & $\begin{array}{l}\text { Flue Dust Sampling Instrument, } \\
\text { Flue Gas Sampling Gun }\end{array}$ & $\begin{array}{l}\text { Raoying 3012H, 1085B, } \\
1085 \mathrm{D}\end{array}$ & $\begin{array}{l}\text { GB/T 16157-1996 } \\
\text { GB 13931-2002 } \\
\text { ISO 12141-2002 }\end{array}$ \\
\hline $\mathrm{SO}_{3}$ Concentrations & $\begin{array}{l}\text { Ultraviolet Spectrophotometer, Flue } \\
\text { Gas Sampling Gun }\end{array}$ & Hach DR5000, ZR-D03A & $\begin{array}{l}\text { GBT 21508-2008 } \\
\text { DL/T 986-2005 }\end{array}$ \\
\hline Dust Practical Resistivity & Dust Practical Resistivity Tester & TH2681A & $\mathrm{GB} / \mathrm{T} 16913-2008$ \\
\hline
\end{tabular}

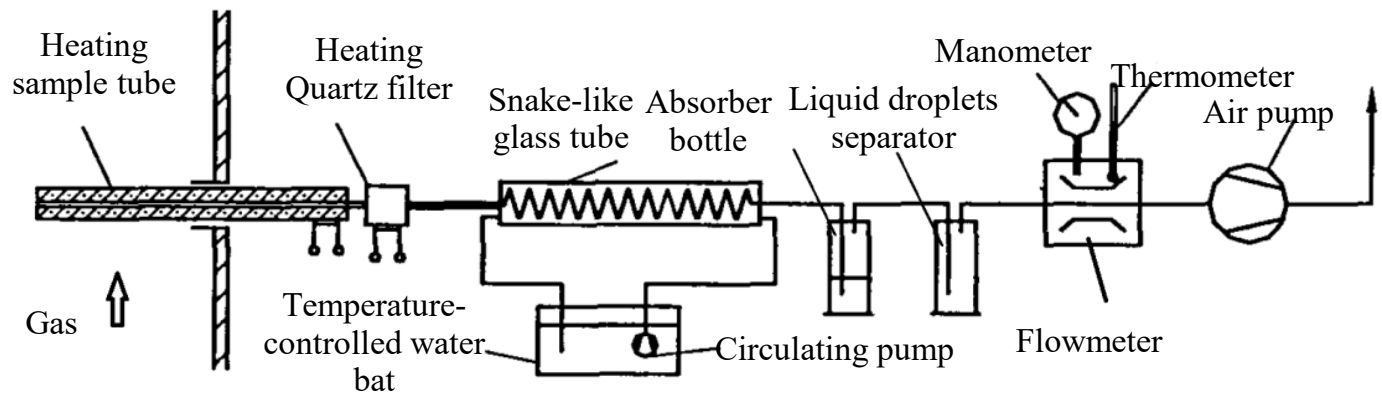

Fig. 3. The measurement method of $\mathrm{SO}_{3}$.

reduced under acid dew point by the $60-65^{\circ} \mathrm{C}$ temperaturecontrolled water bat, and be collected by the snake-like glass tube, depended on the inertial forces. During the test, the constant temperature should not be lower than $60^{\circ} \mathrm{C}$ to prevent $\mathrm{SO}_{2}$ from being condensed. The heating sample tube was set with a quartz filter or a glass fiber to filter the particulate matter and the heating temperature is not lower than $260^{\circ} \mathrm{C}$. The content of $\mathrm{SO}_{4}{ }^{2-}$ was tested by titration method with an ultraviolet spectrophotometer.

\section{RESULTS AND DISCUSSION}

\section{Dust Removal Efficiency with Different Diameters}

The result of the tests done on the LLT-ESP pilot-plan is shown in Fig. 4. It showed that the dust concentration via gas temperature and diameter (Liu et al., 2018). The sizes of dust particles between GGH and LLT-ESP were growing from 130 to $90^{\circ} \mathrm{C}$ and the particles ratio of $\leq 1 \mu \mathrm{m}, \leq 2.5 \mu \mathrm{m}$, $\leq 10 \mu \mathrm{m}$ decreased by $65 \%, 50 \%$ and $35 \%$ respectively. In general, the dusts whose size was in a range of $0.1-1 \mu \mathrm{m}$ were difficult to remove (Zhao et al., 2018). When the temperature reduced, the penetration concentrations of $\mathrm{PM}_{1}$ decreased from 0.5 to $0.17 \mathrm{mg} \mathrm{m}^{-3}$. As the penetration concentration of $\mathrm{PM}_{1}$ decreases about $65 \%$ when the temperature of flue gas decreases to $90^{\circ} \mathrm{C}$ according to the tests, about $60 \%$ of $\mathrm{PM}_{1}$ has grown up to big particle which was easy to collect by ESP.

As the same trend, the tests of LLT-ESP in Changxing plant $(600 \mathrm{MW})$ showed that the penetration efficiency of $\mathrm{PM}_{1}$ decreased $65 \%$ as the gas temperature decreased from 120 to $90^{\circ} \mathrm{C}$ ( $\mathrm{Li}$ et al., 2016). And the total particles concentration (TPS) were less than $11.5 \mathrm{mg} \mathrm{m}^{-3}$ at the outlet of LLT-ESP, contrasted with $19 \mathrm{mg} \mathrm{m}^{-3}$ at the outlet of normal ESP, accorded by the test of Shangan plant. 


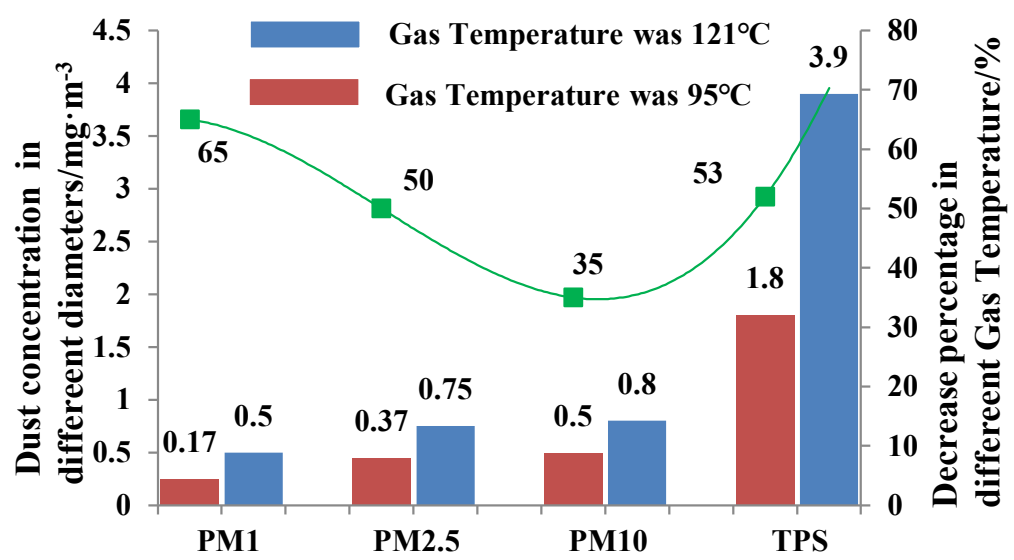

Fig. 4. Dust removing efficiency of different diameters.

The LLT-ESP which reduced the gas temperature to near $95^{\circ} \mathrm{C}$ made a good effect on the performance of ESP and effectively solved the problem of low removal efficiency of fine particles. Moreover, the WFGD would show an apparent increase of dust removal efficiency as the particles diameters increased at the inlet of WFGD when took a LLT-ESP (Ondov et al., 1979).

\section{$\mathrm{SO}_{3}$ Removal Efficiency}

The tests done on the LLT-ESP pilot-plan showed that the removal efficiency of $\mathrm{SO}_{3}$ was $22.84 \%, 96.15 \%$ and $96.61 \%$ when the gas temperature was $120^{\circ} \mathrm{C}, 90^{\circ} \mathrm{C}$ and $80^{\circ} \mathrm{C}$ (Wu et al., 2018), respectively. Furthermore, the tests done on the LLT-ESP in Changxing plant showed that the removal efficiency of $\mathrm{SO}_{3}$ achieved $73 \%$ by GGH and LLT-ESP, and the $\mathrm{SO}_{3}$ concentration was less than $6 \mathrm{mg} \mathrm{m}^{-3}$, as shown in Fig. 5, while the penetration concentration of $\mathrm{PM}$ decreased from 28 to $18 \mathrm{mg} \mathrm{m}^{-3}$. $\mathrm{SO}_{3}$ removal efficiency is increased with LLT-ESP.

\section{Mechanism Analysis of Fine Particles Change and $\mathrm{SO}_{3}$ Removal}

To analyze the mechanism of fine particles change and
$\mathrm{SO}_{3}$ removal, membranes was set at the inlet of ESP in the pilot-scale platform, and particulate matter was observed by scanning electron microscope (Yao et al., 2016).

Contrast of $120^{\circ} \mathrm{C}$, the particulate matters in the gas temperature of $90^{\circ} \mathrm{C}$ got together, and the fine particulate adhered to coarse particulate.

As the flue gas before ESP includes relatively much PM than $\mathrm{SO}_{3}$, the gas $\mathrm{SO}_{3}$ condensed into $\mathrm{SO}_{3}$ mist and was condensed on PM when the flue gas temperature was reduced below acid dew point. According the analysis, the rule of condensation, adsorption, the model of fine particles change and $\mathrm{SO}_{3}$ removal was put forward as shown in Fig. 6, which supports the test results of dust particles grow when the flue gas decreases to $90^{\circ} \mathrm{C}$ in Fig. 4. At the same time, the $\mathrm{SO}_{3}$ would be collected together with $\mathrm{PM}$ and solved the high penetration rate of $\mathrm{SO}_{3}$ of normal ESP in 120$130^{\circ} \mathrm{C}$.

\section{CONCLUSIONS}

When the gas temperature in a coal-fired power plant decreased from $120-130^{\circ} \mathrm{C}$ to $90-95^{\circ} \mathrm{C}$, the particulate matter aggregated and adhered to coarse particles, and the

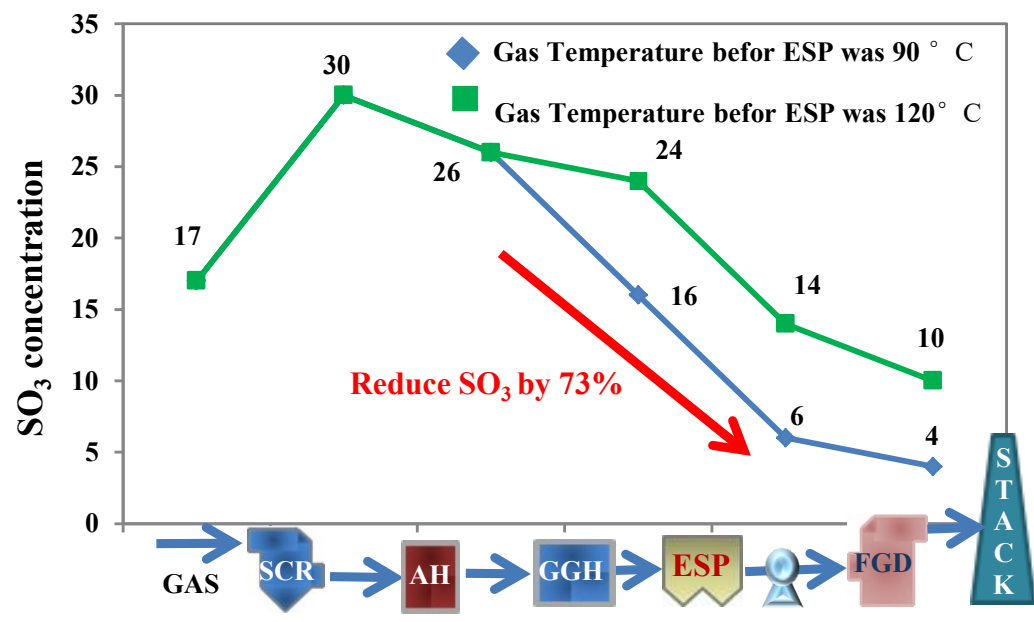

Fig. 5. $\mathrm{SO}_{3}$ removal performance vs. gas temperature. 


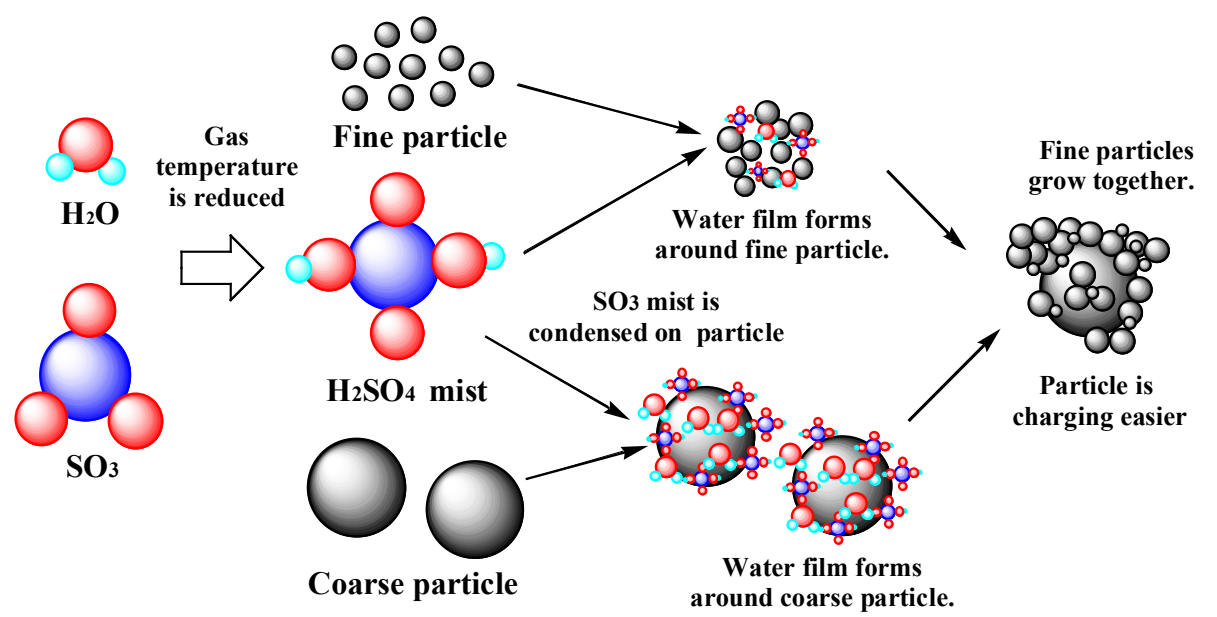

Fig. 6. Model of fine particle change and $\mathrm{SO}_{3}$ removal Model images.

gaseous $\mathrm{SO}_{3}$ condensed into $\mathrm{SO}_{3}$ mist and on the PM. The problem of charging fine dust particles was negated by reducing the flue gas temperature below the acid dew point, as most of the $\mathrm{PM}_{1}$ developed into large particles, which were easily collected by the ESP. More than $70 \%$ of the $\mathrm{SO}_{3}$ was removed with the $\mathrm{PM}$, and the penetration concentration of the $\mathrm{PM}_{1}$ decreased from 0.5 to $0.17 \mathrm{mg} \mathrm{m}^{-3}$.

\section{ACKNOWLEDGMENTS}

This work was supported by the financial support from National Key R\&D Program of China (No. 2017YFB0603202).

\section{REFERENCES}

Afshar-Mohajer, N., Thakker, Y., Wu, C.Y. and SorloaicaHickman, N. (2014). Influence of back electrostatic field on the collection efficiency of an electrostatic lunar dust collector. Aerosol Air Qual. Res. 14: 1333-1343.

Ando, H., Shiromaru, N. and Mochizuki, Y. (2011). Recent technology of moving electrode electrostatic precipitator. Int. J. Plasma Environ. Sci. Technol. 200: 130-134.

Chang, Q., Zheng, C., Gao, X., Chiang, P., Fang, M., Luo, Z. and Cen, K. (2015). Systematic approach to optimization of submicron particle agglomeration using ionic-wind-assisted pre-charge. Aerosol Air Qual. Res. 15: 2709-2719.

China Association of Environmental Protection Industry. (2015). Technology of flue gas ultra-low emission for coal-fired power plant. China Electric Power Press, Beijing.

GB/T 16913-2008 (2008). Methods of dust character test. General Administration of Quality Supervision, Inspection and Quarantine of the People's Republic of China, Standardization Administration of the People's Republic of China, China. (in Chinese)

GB/T 21508-2008 (2008). Performance test method for coal-fired flue gas desulphurization equipment. General Administration of Quality Supervision, Inspection and
Quarantine of the People's Republic of China, Standardization Administration of the People's Republic of China, China. (in Chinese)

He, Y., Zhao, H. and Wu., Y. (2013). Technical agreement of low-low temperature electrostatic precipitator in Changxing plant. Technical Agreement, Zhejiang. (in Chinese)

ISO 12141-2002 (2002). Stationary source emissionsDetermination of mass concentration of particulate matter (dust) at low concentrations - Manual gravimetric method. International Organization for Standardization, Switzerland.

JB/T 12591-2016 (2016). Low-low temperature electrostatic precipitator. Ministry of Industry and Information Technology (in Chinese)

Kato, M., Tanaka, T., Nishimura, Y., Yata, K., Nakao, M. and Sakai, T., Ohishi, T. and Higashi, T. (1994). Method and system for handling exhaust gas in a boiler. US5282429, US.

Li, Q., Li, W. and Qiu, X. (2016). In-depth test report on collaborative flue gas Control of Huaneng Changxing Power Plant; School of Environment, Tsinghua University, China, Test Report. (in Chinese)

Li, J., He, Y., Liu, H. and Zhao, H. (2017). Characteristics of low-low temperature ESP technology and its application in ultra-low emissions for high-ash coal-fueled power plant. Electric Power 50: 28-33. (in Chinese)

Liu, H., Li, J., Yao, Y., He, Y., Chen, Z. and Wang, P. (2018). Fly ash particle characterization of electrostatic precipitators and cooling agglomeration for fine particles. Chem. Ind. Eng. Prog. 37: 2413-2425. (in Chinese)

Misaka, T. and Mochizuki, Y. (2008). Recent application and running cost of moving electrode type electrostatic precipitator. $11^{\text {th }}$ International Conference on Electrostatic Precipitation. Hangzhou, China.

Misaka, T. and Mochizuki, Y. (2009). Recent application and running cost of moving electrode type electrostatic precipitator. In Electrostatic precipitation, Yan, K. (Ed.), Springer Berlin Heidelberg, Berlin, Heidelberg, pp. 518-522. 
Nicol, K. (2013). Recent developments in particulate control. IEA Clean Coal Centre, UK, pp. 29-30.

Ondov, J.M., Ragaini, R.C. and Biermann, A.H. (1979). Emissions and particle-size distributions of minor and trace elements at two western coal-fired power plants equipped with cold-side electrostatic precipitators. Environ. Sci. Technol. 13: 946-953.

Preston, J.M., Watson, W.R. and Jones, C.B. (2013). Waste/low quality heat recovery and utilization with low temperature economizers. ASME 2013 Power Conference, pp.V001T01A015-V001T01A015.

Roudier, S., Sancho, L.D., Remus, R. and Aguadomonsonet, M. (2013). Best Available Techniques (BAT) reference document for iron and steel production. Industrial Emissions Directive 2010/75/EU: Integrated Pollution Prevention and Control. Institute for Prospective and Technological Studies, Joint Research Centre, European Commission.

Saeki, M., Inoue, T., Tsukahara, M. and Maehata, H. (2003). Development of electrostatic separator equipped with moving belt electrode. Trans. Jpn. Soc. Mech. Eng. C 69: 3358-3363.

Tamaru, T. (1998). Operation results of IHI flue gas desulfurization system for Unit No. 1 (700 MW) of Reihoku power station of Kyushu Electric Power Co., Inc. IHI Eng. Rev. 30: 60-68.

Wu, J., Liu, H., Li, J., Zhao, L. and Luo, J. (2018). The indepth experimental study on the low low-temperature electrostatic precipitator based in pilot platform. Electrc. Power 51: 11-16. (in Chinese)

Xia, J., Peng, P., Zhang, C., Yang, T. and Chen, G. (2011). Study and application of two-level optimization of coal blending for power plant based on on-line coal identification. ASME 2011 Power Conference collocated with JSME ICOPE 2011, ASME 2011 Power Conference, Volume 1, Denver, Colorado, USA, July 12-14, 2011, pp. 221-226.

Xu, X., Gao, X., Yan, P., Zhu, W., Zheng, C., Wang, Y., Luo, Z. and Cen, K. (2015). Particle migration and collection in a high-temperature electrostatic precipitator. Sep. Purif. Technol. 143: 184-191.

Yao, Y., He, Y. and Li, J. (2016). Acceptance report of 863 project (2013AA065002). Development of efficiency enhancement and optimization technology and equipment for $\mathrm{PM}_{2.5}$ collection in coal-fired power stations, National High-tech Research and Development Program of China (863 Program) Project selfacceptance report, Zhejiang Feida environmental science \& technology Co., Ltd., China. (in Chinese)

Yi, H., Hao, J., Duan, L., Li, X. and Guo, X. (2006). Characteristics of inhalable particulate matter concentration and size distribution from power plants in China. J. Air Waste Manage. Assoc. 56: 1243-1251.

Zhao, H., Wang, X. and Xu, J. (2016). Technical agreement of low temperature electrostatic precipitator in pilot scale. Technical Agreement, Zhejiang. (in Chinese)

Zhao, H., He, Y. and Yao, Y. (2018). Study on brush of moving electrode type electrostatic precipitator (MEEP). IOP Conference Series: Earth and Environmental Science 121: 052024

Received for review, May 28, 2018

Revised, July 19, 2018

Accepted, July 30, 2018

Corrected, November 2, 2021 